\title{
Protective effect of black garlic extracts on tert-Butyl hydroperoxide-induced injury in hepatocytes via a c-Jun N-terminal kinase-dependent mechanism
}

\author{
KO-CHAO LEE ${ }^{1}$, CHIH-CHUAN TENG ${ }^{2}$, CHIEN-HENG SHEN ${ }^{3,4}$, WEN-SHIH HUANG $^{5}$, \\ CHIEN-CHANG LU ${ }^{1}$, HSING-CHUN KUO ${ }^{3,6,7}$ and SHUI-YI TUNG ${ }^{3,8}$
}

\begin{abstract}
${ }^{1}$ Division of Colorectal Surgery, Department of Surgery, Chang Gung Memorial Hospital, Kaohsiung Medical Center, Chang Gung University College of Medicine, Kaohsiung 833; ${ }^{2}$ Department of Nursing, Chang Gung University of Science and Technology; ${ }^{3}$ Department of Hepato-Gastroenterology, Chang Gung Memorial Hospital, Chiayi 613; ${ }^{4}$ Graduate Institute of Clinical Medical Sciences, College of Medicine, Chang Gung University, Taoyuan 333; ${ }^{5}$ Division of Colon and Rectal Surgery, Department of Surgery, Chang Gung Memorial Hospital Chiayi; ${ }^{6}$ Chronic Diseases and Health Promotion Research Center, CGUST, Chiayi 613; ${ }^{7}$ Research Center for Industry of Human Ecology and Research Center for Chinese Herbal Medicine, College of Human Ecology, Chang Gung University of Science and Technology, Taoyuan 333; ${ }^{8}$ School of Medicine, Chang Gung University, Taoyuan 333, Taiwan, R.O.C.
\end{abstract}

Received November 18, 2015; Accepted December 9, 2016

DOI: $10.3892 /$ etm.2018.5719

\begin{abstract}
Black garlic has been reported to show multiple bioactivities against the development of different diseases. In the present study, the hepatoprotective effect of black garlic on injured liver cells was investigated. Rat clone- 9 hepatocytes were used for all experiments; tert-Butyl hydroperoxide (tBHP) was used to induce injury of rat clone-9 hepatocytes. The contents of malondialdehyde (MDA) and glutathione (GSH); anti-oxidative enzyme activities of catalase (CAT), superoxide dismutase (SOD), glutathione peroxidase (GPx); and mRNA expression levels of interleukin (IL)-6 and IL-8 in rat clone-9 hepatocytes were determined to evaluate the level of cell damage. Black garlic extracts were demonstrated to significantly attenuate tBHP-induced cell death of rat clone-9 hepatocytes $(\mathrm{P}<0.05)$. Pretreatment with black garlic extracts antagonized GSH depletion, tBHP-increased MDA accumulation and the mRNA expression level of IL-6/IL-8, and tBHP-decreased antioxidative enzyme activities (all $\mathrm{P}<0.05$ ). Moreover, the present study revealed that c-Jun N-terminal kinase signaling regulated black garlic-inhibited tBHP effects in rat clone-9 hepatocytes. Our findings demonstrate that black garlic has the hepatoprotective potential to block tBHP-damaged effects on cell death, lipid peroxidation,
\end{abstract}

Correspondence to: Dr Shui-Yi Tung, Department of Hepato-Gastroenterology, Chang Gung Memorial Hospital, 6 Sec. W., Jiapu Road, Puzi, Chiayi 613, Taiwan, R.O.C.

E-mail: trxcnchen@gmail.com

Key words: black garlic, hepatoprotective, lipid peroxidation, oxidative stress, tert-Butyl hydroperoxide oxidative stress, and inflammation in rat clone-9 hepatocytes. Thus, the present study indicates that black garlic may be an excellent natural candidate in the development of adjuvant therapy and healthy foods for liver protection.

\section{Introduction}

Garlic has frequently been used in gastronomy for centuries. However, accumulating data have demonstrated other useful elements of garlic, such as its bioactivities on cancer prevention, and anti-microbial, anti-oxidation, and insecticidal properties (1-5). In spite of these beneficial effects, numerous individuals do not enjoy raw garlic due to the pungent odor released by the compound allicin (1,5-7). Therefore, modified forms of garlic have been prepared to reduce this unpleasant odor. Black garlic, a garlic preparation, is formed by incubating raw garlic in an environment of high temperature and humidity, which initiates a non-enzymatic browning reaction to transfer the allicin into water-soluble compounds, such as S-allylcysteine and S-allyl melcaptocysteine, enabling the efficient removal of the pungent smell (1,7-9). In vivo and in vitro experiments have demonstrated that black garlic is able to retain the original bioactivities of raw garlic on clinical application (10-12). Moreover, the anti-oxidation effect of black garlic is even stronger than that of raw garlic (1). In addition, novel functions of black garlic have also continued to be reported, including its protective effects against diabetes, allergies and liver injury (10-12).

The liver is an important metabolic organ with various complex physiological functions, including nutrient metabolism (lipids, proteins and carbohydrates) and waste excretion and detoxification (13-16). Liver injury, initiated by exposure to high levels of environmental toxins, results in metabolic dysfunctions and subsequent elevation of inflammation and oxidative stress (13-16). Moreover, the levels of inflammatory 
cytokines, such as IL-6 and IL-8, and reactive oxygen species (ROS) within the tissue rapidly accumulate, damaging the liver. In order to prevent further injury, the defense system, specifically the immune system and anti-oxidative enzymes, including catalase (CAT), superoxide dismutase (SOD), and glutathione peroxidase (GPx), are activated to eliminate these harmful factors (14,17-19).

To stimulate cell and tissue damage, tert-Butyl hydroperoxide (tBHP) is commonly used as a hepatocytotoxic agent $(19,20)$. In cells, tBHP is metabolized through two pathways: i) tBHP is metabolized by cytochrome P450 and results in increases in peroxyl and alkoxyl radicals to initiate lipoperoxidation of membrane lipids and production of malondialdehyde (MDA); and ii) tBHP is detoxified to tert-butanol and results in rapid glutathione (GSH) oxidation (19-21). Both pathways lead to liver cell injury. Thus, the use of tBHP-treated cells is a well-recognized experimental model in laboratory investigation. Moreover, the levels of MDA and GSH are critical indicators of lipid peroxidation.

In the present study the hepatoprotective effect of black garlic on tBHP-stimulated rat clone- 9 hepatocytes and the underlying mechanism responsible was determined using antioxidative enzyme activity analysis, reverse transcription-quantitative polymerase chain reaction (RT-qPCR) and western blotting. The contents of MDA and GSH; anti-oxidative enzyme activities of CAT, SOD, GPx; and mRNA expression levels of IL- 6 and IL- 8 were determined to evaluate the level of cell damage. Black garlic efficiently attenuated tBHP-initiated cell death, lipid peroxidation, oxidative stress and inflammation in rat clone- 9 hepatocytes. Moreover, this attenuation may be accomplished through c-Jun N-terminal kinase (JNK) signaling. Thus, this study indicated that black garlic provides a protective effect on injured liver cells and thus may be applied in adjuvant therapy and health foods for the management of liver injury.

\section{Materials and methods}

Materials. MDA assay kit (LPO-586) was purchased from EMD Millipore (Billerica, MA, USA). GSH (CS0260), CAT (CAT100), SOD (19160) and GPx (CGP1) activity assay kits were obtained from Sigma-Aldrich (Merck Millipore, Darmstadt, Germany). Mouse monoclonal antibodies against JNK1/2 (sc-7345) and phospho-JNK1/2 (sc-6254) were purchased from Santa Cruz Biotechnology. All other chemicals were of reagent grade and purchased from Sigma-Aldrich (Merck Millipore), unless stated otherwise.

Cell cultures. Rat clone-9 hepatocytes were supplied by the Food Industry Research and Development Institute (Taiwan, China). Hepatocytes were grown in Dulbecco's modified Eagle's medium (DMEM), supplemented with $10 \%$ fetal bovine serum and 1\% penicillin/streptomycin (all Invitrogen; Thermo Fisher Scientific, Inc., Waltham, MA, USA) and maintained in an atmosphere containing $5 \% \mathrm{CO}_{2}$ at $37^{\circ} \mathrm{C}$, using an incubator.

Preparation of black garlic extract. Unpeeled raw garlic heads were incubated at $70^{\circ} \mathrm{C}$ in $90 \%$ relative humidity for 35 days using a thermohygrostatic chamber. Black garlic was subsequently combined with deionized water at a solid:liquid ratio of 1:10. Samples were obtained with deionized water for $30 \mathrm{~min}$ at room temperature using an ultrasonic bath (Taiwan Supercritical Technology Co., Ltd., Fenyuan, Taiwan). Extracts were centrifuged $\left(2,500 \mathrm{x} \mathrm{g} ; 10 \mathrm{~min} ; 4^{\circ} \mathrm{C}\right)$ and supernatants were collected. Supernatants were subsequently dried using a freeze-dryer (Labconco freeze-dry/shell freeze system; Labconco Corp., Kansas City, MO, USA) and the dried extracts were stored at $-20^{\circ} \mathrm{C}$ prior to analysis.

Cell viability assay. Cell viability was determined using an MTT assay. Cells were cultured at a density of $\times 10^{4}$ cells $/ \mathrm{cm}^{2}$ on 96 -well plates. Following stimulation, $0.5 \mathrm{mg} / \mathrm{ml}$ of MTT solution was added to each well and the mixture was incubated at $37^{\circ} \mathrm{C}$ for $3 \mathrm{~h}$. Formazan crystals were dissolved by adding dimethyl sulfoxide solution and absorbance was measured at $570 \mathrm{~nm}$ using a spectrophotometer.

MDA assay for lipid peroxidation. Cells were cultured in a monolayer on 24-well plates. Following stimulation, the culture medium was replaced with $0.5 \mathrm{ml}$ cell lysis buffer after three washes with PBS. MDA contents were then determined using an MDA assay kit, according to the manufacturer's instructions.

GSH level and CAT/SOD/GPx enzyme activity assay. Cells were cultured in a monolayer on 24-well plates. Following stimulation, the levels of GSH, CAT, SOD, and GPx enzyme activities in rat clone-9 hepatocytes were measured in triplicate using commercial assay kits, according to manufacturers' instructions.

Western blot analysis. Cells were collected and lysed with radio immunoprecipitation assay buffer (1\% NP-40, $0.5 \%$ sodium deoxycholate, $0.1 \%$ SDS and protease/phosphatase inhibitor cocktail). Total cell lysate concentrations were determined using a protein assay kit (Bio-Rad Laboratories, Inc., Hercules, CA, USA). Proteins $(50 \mu \mathrm{g} / \mathrm{ml})$ were separated by SDS-PAGE (10\% running and $4 \%$ stacking). Equal amounts of protein from the control and experimental groups was suspended in 5X sample buffer and distilled water and boiled for $10 \mathrm{~min}$, then subjected to SDS-PAGE. The electrophoresis was carried out for $2 \mathrm{~h}$ and the separated proteins were transferred to a nitrocellulose membrane. Following blocking with 5\% skim milk for $1 \mathrm{~h}$ at room temperature, the membrane was blotted with the JNK-(sc-7345) and phosphor-JNK (sc-6254; both Santa Cruz Biotechnology) specific primary antibody (diluted in 1:500) overnight at $4^{\circ} \mathrm{C}$. The membranes were washed with Tris-buffered saline with Tween-20 buffer, they were blotted with anti-mouse secondary antibody (1:3,000; cat. no. 7076; Cell Signaling Technology, Inc., Danvers, MA, USA) for $2 \mathrm{~h}$ at room temperature. Immunodetection was performed by using a western light chemiluminescent detection system (Applied Biosystems; Thermo Fisher Scientific Inc.).

$R T$ - $q P C R$. RNA was isolated from the rat clone-9 hepatocytes. The collected samples were homogenized with TRIzol (Invitrogen; Thermo Fisher Scientific, Inc.) by rotor-stator homogenizer, and then placed on the benchtop at room temperature for $5 \mathrm{~min}$. Each sample was added to $0.2 \mathrm{ml}$ chloroform and agitated vigorously for $15 \mathrm{sec}$ to mix completely. The samples were kept on the benchtop at room temperature for 2-3 min then 
A

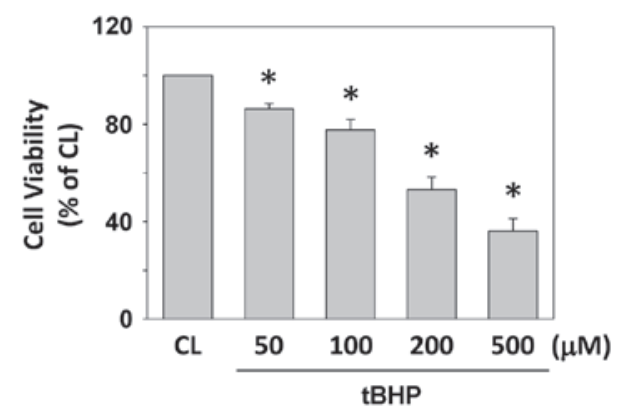

B

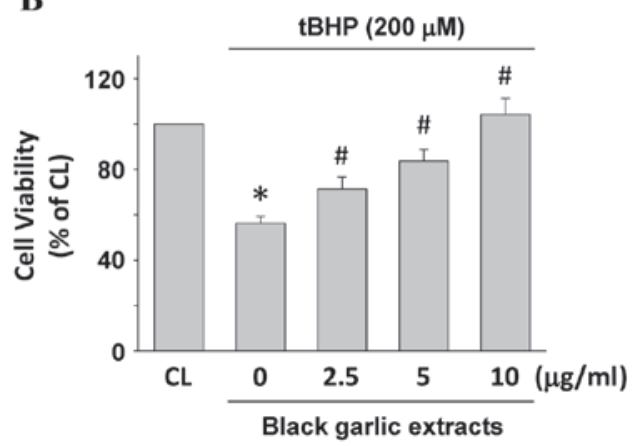

Figure 1. Black garlic extract attenuates tBHP-induced cell death of rat clone-9 hepatocytes. (A) Cells were kept as CL or were stimulated with tBHP at 50, 100,200 and $500 \mu \mathrm{M}$ for $24 \mathrm{~h}$ and cell viability was determined by MTT assay. (B) Cells were kept as CL or were treated with tBHP at $200 \mu \mathrm{M}$ for $24 \mathrm{~h}$. Prior to stimulation with tBHP, cells were pretreated with $0-10 \mu \mathrm{g} / \mathrm{ml}$ black garlic extract for $1 \mathrm{~h}$. Data are presented as the mean \pm standard error of the mean from four independent experiments. " $\mathrm{P}<0.05$ vs. CL cells; ${ }^{~} \mathrm{P}<0.05$ vs. cells treated with tBHP only. tBHP, tert-Butyl hydroperoxide; CL, control.

centrifuged at $12,000 \mathrm{x}$ for $15 \mathrm{~min}$ at $4^{\circ} \mathrm{C}$. The upper phase was transferred to new tubes and $0.5 \mathrm{ml}$ isopropanol was added. The samples were mixed gently and placed on the benchtop at room temperature for $10 \mathrm{~min}$ prior to centrifugation at $12,000 \mathrm{x} \mathrm{g}$ for $10 \mathrm{~min}$ at $4^{\circ} \mathrm{C}$. The supernatant was discarded and $1 \mathrm{ml} 75 \%$ ethanol was added per tube. This was then centrifuged at 7,500 x g for $5 \mathrm{~min}$ at $4^{\circ} \mathrm{C}$. The supernatant was removed completely and briefly left to air-dry the RNA pellet. The RNA was re-dissolved in an appropriate volume (15 $\mu \mathrm{l})$ of RNase-free water. DNase was added to remove genomic DNA.

The reverse transcription steps were carried out by using Thermo RevertAid First Strand cDNA Synthesis kit (Thermo Fisher Scientific, Inc.) and BioRad C1000 Thermal Cycler (Bio-Rad Laboratories, Inc.). Initially, $5 \mu \mathrm{g}$ total RNA and $1 \mu 1$ Oligo (dT) 18 primer and complement was added to the RNase-free tubes and the volume was made up to $12 \mu \mathrm{l}$ with distilled water. The mixtures were incubated at $65^{\circ} \mathrm{C}$ for $5 \mathrm{~min}$ then chilled on ice. Each tube was then further administered $5 \mu 15 X$ Reaction Buffer, $1 \mu$ l RiboLock RNase Inhibitor (20 U/ $\mu \mathrm{l}), 2 \mu \mathrm{l} 10 \mathrm{mM}$ dNTP Mix and $1 \mu \mathrm{l}$ RevertAid M-MuLV RT $(200 \mathrm{U} / \mu \mathrm{l})$ to give a final total volume of $20 \mu \mathrm{l}$. The mixtures were incubated at $42^{\circ} \mathrm{C}$ for $60 \mathrm{~min}$ to allow cDNA synthesis and then increased to $70^{\circ} \mathrm{C}$ for $10 \mathrm{~min}$ to terminate the reaction.

PCR was performed using an ABI Prism 7900HT (Applied Biosystems; Thermo Fisher Scientific, Inc.) according to the manufacturer's protocol. Amplification of specific PCR products was detected using SYBR-Green PCR Master Mix (Applied Biosystems; Thermo Fisher Scientific, Inc.). The designed primers in this study were as follows: For PAI-1, forward 5'-CATCCCCCATCCTACGTGG-3', reverse 5'-CCC CATAGGGTGAGAAAACCA-3'; for PKC, forward 5'-ATT CTATGCGGCAGAGATTTCC-3', reverse 5'-TCCTTCTGA ATCCAACATGACG-3'.

RNA samples were normalized to the levels of GAPDH and 18S rRNA. All primer pairs had at least 1 primer crossing an exon-exon boundary. The RT-qPCR was performed in triplicate in a total reaction volume of $20 \mathrm{ml}$ containing $10 \mathrm{ml}$ of SYBR Green PCR Master Mix, $300 \mathrm{nM}$ forward and reverse primers, $4 \mathrm{ml}$ of distilled $\mathrm{H}_{2} \mathrm{O}$, and $4 \mathrm{ml}$ of complementary DNA from each sample. Samples were heated for $10 \mathrm{~min}$ to $95^{\circ} \mathrm{C}$ and amplified for 40 cycles of $95^{\circ} \mathrm{C}$ for $15 \mathrm{sec}$ and $60^{\circ} \mathrm{C}$ for $60 \mathrm{sec}$. Quantification was performed using the $2^{-\Delta \Delta \mathrm{Cq}}$ method (22), where the $\mathrm{Cq}$ value was defined as the threshold cycle of PCR at which amplified product was detected. The $\Delta \mathrm{Cq}$ value was obtained by subtracting the $\mathrm{Cq}$ value of the housekeeping gene (GAPDH or $18 \mathrm{~S}$ rRNA) from the $\mathrm{C}_{\mathrm{q}}$ value of the gene of interest. The present study used the $\Delta \mathrm{C}_{\mathrm{q}}$ value of controls as the calibrator. The fold change was calculated according to the formula $2^{-\Delta \Delta \mathrm{Cq}}$, where $\Delta \Delta \mathrm{C}_{\mathrm{q}}$ was the difference between the $\Delta \mathrm{Cq}$ value and the $\Delta \mathrm{Cq}$ calibrator value.

Statistical analysis. Results are expressed as mean \pm standard error of the mean. Statistical analysis was determined via an independent Student t-test for two groups of data and analysis of variance followed by Scheffe's test for multiple comparisons. $\mathrm{P}<0.05$ was considered to indicate a statistically significant difference.

\section{Results}

Black garlic extracts attenuate tBHP-induced cell death of rat clone-9 hepatocytes. Cells were kept as the control or were treated with tBHP at 50,100, 200 and $500 \mu \mathrm{M}$ for $24 \mathrm{~h}$ to determine the cell viability of rat clone- 9 hepatocytes. Treating cells with $\mathrm{tBHP}$ resulted in the significant cell death of rat clone-9 hepatocytes in a dose-dependent manner, as compared with the untreated control $(\mathrm{P}<0.05$; Fig. 1A). To investigate the protective effect of black garlic extracts on tBHP-treated cells, rat clone-9 cells were kept as the control or were pretreated with black garlic extracts at $0,2.5,5$ or $10 \mu \mathrm{g} / \mathrm{ml}$ for $1 \mathrm{~h}$. Black garlic extract-pretreated cells were treated with tBHP $(200 \mu \mathrm{M})$ for $24 \mathrm{~h}$. Black garlic extract significantly restored the cell viability of tBHP-treated rat clone-9 hepatocytes (Fig. 1B, $\mathrm{P}<0.05$ ).

Black garlic extracts inhibit tBHP-increased MDA accumulation and GSH depletion in rat clone-9 hepatocytes. MDA and GSH levels in the cells were used to evaluate lipid peroxidation and oxidative stress in rat clone- 9 hepatocytes. Rat clone-9 hepatocytes were kept as the control or were pretreated with black garlic extracts at $0,2.5,5$ or $10 \mu \mathrm{g} / \mathrm{ml}$ for $1 \mathrm{~h}$. Black garlic extract-pretreated cells were treated with tBHP $(200 \mu \mathrm{M})$ for 24 h. MDA (Fig. 2A) and GSH (Fig. 2B) levels were significantly increased and diminished, respectively, in the tBHP-treated cells as compared with the 
A

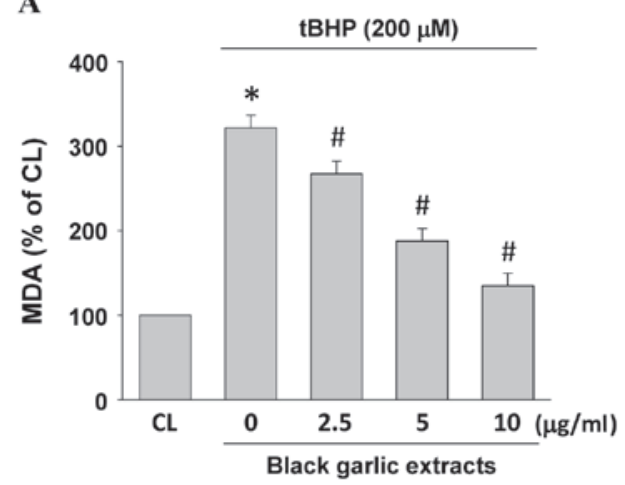

B

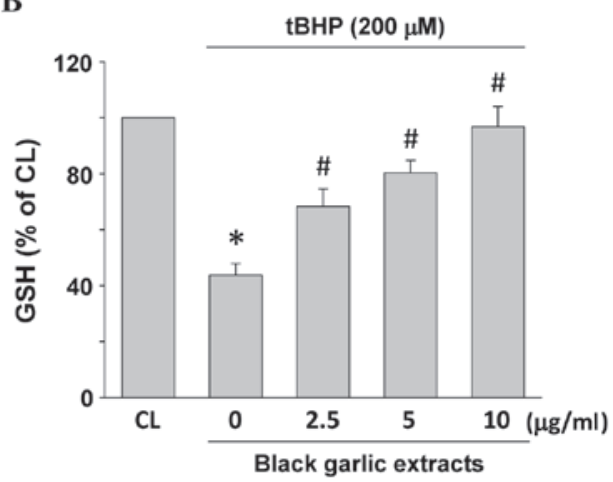

Figure 2. Black garlic extract inhibits tBHP-increased MDA accumulation and GSH depletion in rat clone-9 hepatocytes. Cells were kept as CL or were treated with tBHP at $200 \mu \mathrm{M}$ for $24 \mathrm{~h}$. Prior to stimulation with tBHP, cells were pretreated with $0-10 \mu \mathrm{g} / \mathrm{ml}$ black garlic extract for $1 \mathrm{~h}$. Levels of (A) MDA and (B) GSH were determined by commercial assay kits. Data are presented as the mean \pm standard error of the mean from three independent experiments. ${ }^{*} \mathrm{P}<0.05$ vs. CL cells; ${ }^{~} \mathrm{P}<0.05$ vs. cells treated with tBHP only. tBHP, tert-Butyl hydroperoxide; $\mathrm{CL}$, control; MDA, malondialdehyde; GSH, glutathione.

A

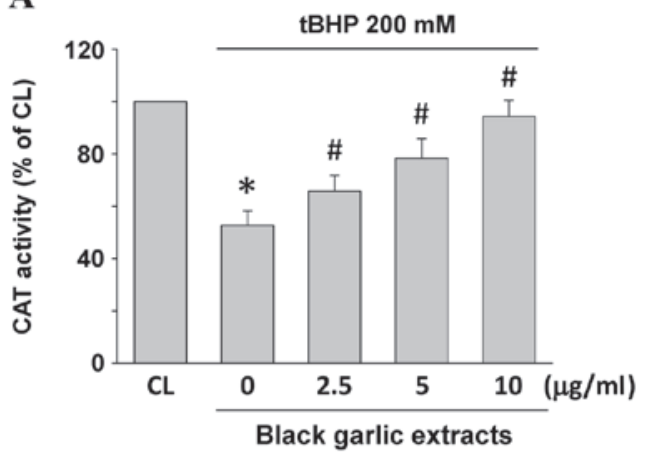

B

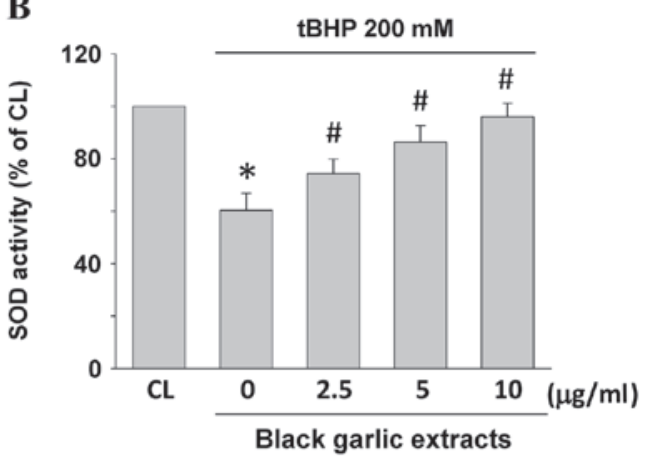

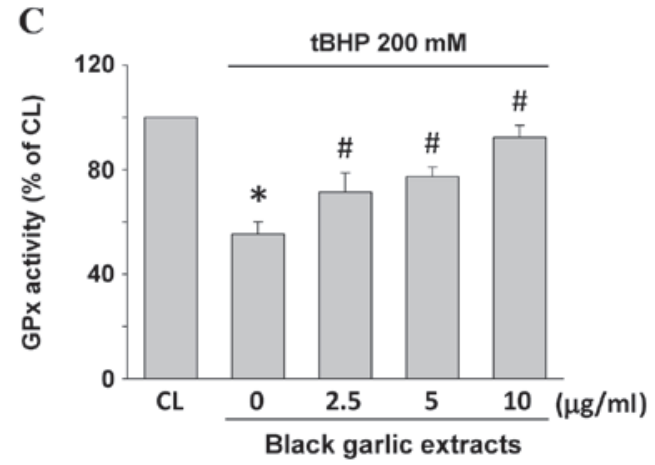

Figure 3. Black garlic extract recovers tBHP-decreased antioxidant enzyme activity in rat clone-9 hepatocytes. Cells were kept as control or were treated with tBHP at $200 \mu \mathrm{M}$ for $24 \mathrm{~h}$. Prior stimulation with tBHP, cells were pretreated with $0-10 \mu \mathrm{g} / \mathrm{ml}$ black garlic extract for $1 \mathrm{~h}$. Enzyme activities of (A) CAT, (B) SOD and (C) GPx were determined by commercial assay kits. Data are presented as the mean \pm standard error of the mean from three independent experiments. ${ }^{*} \mathrm{P}<0.05$ vs. CL cells; " $\mathrm{P}<0.05$ vs. cells treated with tBHP only. tBHP, tert-Butyl hydroperoxide; CL, control; MDA, malondialdehyde; GSH, glutathione; GPx, glutathione peroxidase; CAT, catalase; SOD, superoxide dismutase.

control $(\mathrm{P}<0.05)$. However, black garlic extracts significantly restored the tBHP-increased MDA levels (Fig. 2A, $\mathrm{P}<0.05$ ) and tBHP-diminished GSH levels (Fig. $2 \mathrm{~B}, \mathrm{P}<0.05$ ) in a dose-dependent manner in rat clone- 9 hepatocytes.

Black garlic extracts recover $t B H P$-decreased antioxidant enzyme activity in rat clone-9 hepatocytes. Antioxidative activity of SOD, CAT and GPx may also be indicators of oxidative stress in cells. Rat clone-9 hepatocytes were kept as the control or were pretreated with black garlic extracts at $0,2.5,5$ and $10 \mu \mathrm{g} / \mathrm{ml}$, respectively, for $1 \mathrm{~h}$. Subsequently, black garlic extract-pretreated cells were treated with $\mathrm{tBHP}(200 \mu \mathrm{M})$ for 24 h. CAT (Fig. 3A), SOD (Fig. 3B) and GPx (Fig. 3C) enzyme activities significantly decreased in the tBHP-treated cells as compared with the control $(\mathrm{P}<0.05)$. However, black garlic extracts significantly restored the tBHP-decrease of all three types of enzyme activities in a dose-dependent manner in rat clone-9 hepatocytes $(\mathrm{P}<0.05)$.

Black garlic extracts inhibit tBHP-induced IL-6 and IL-8 mRNA expression levels in rat clone-9 hepatocytes. To determine whether black garlic extracts elicit an anti-inflammatory 
A

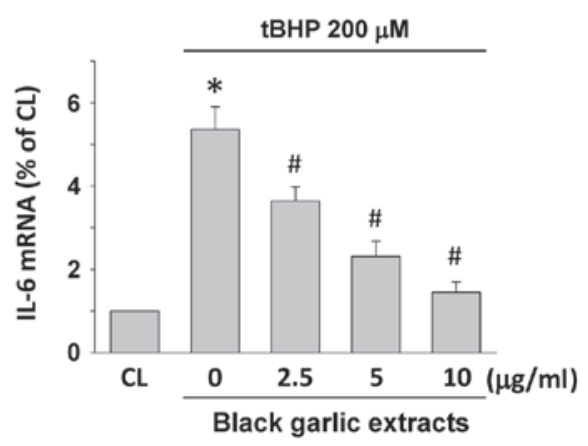

B

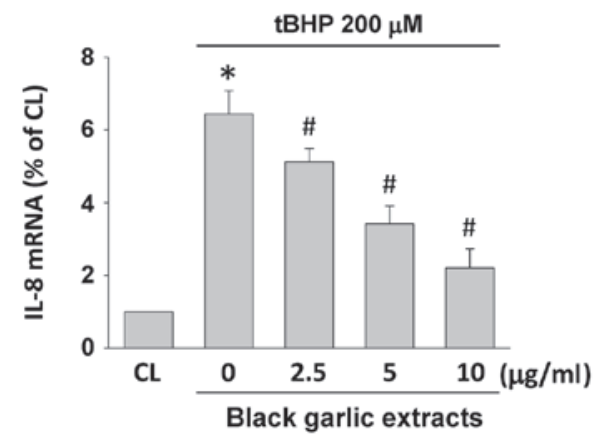

Figure 4. Black garlic extract inhibits tBHP-induced IL-6 and IL-8 mRNA expression levels in rat clone-9 hepatocytes. Cells were kept as CL or were treated with tBHP at $200 \mu \mathrm{M}$ for $24 \mathrm{~h}$. Prior to stimulation with tBHP, cells were pretreated with $0-10 \mu \mathrm{g} / \mathrm{ml}$ black garlic extract for $1 \mathrm{~h}$. mRNA expression levels of (A) IL-6 and (B) IL-8 were determined by reverse transcription-quantitative polymerase chain reaction assay. Data are presented as the mean \pm standard error of the mean from three independent experiments. ${ }^{*} \mathrm{P}<0.05$ vs. CL cells; ${ }^{\#} \mathrm{P}<0.05$ vs. cells treated with tBHP only. tBHP, tert-Butyl hydroperoxide; CL, control; IL, interleukin.

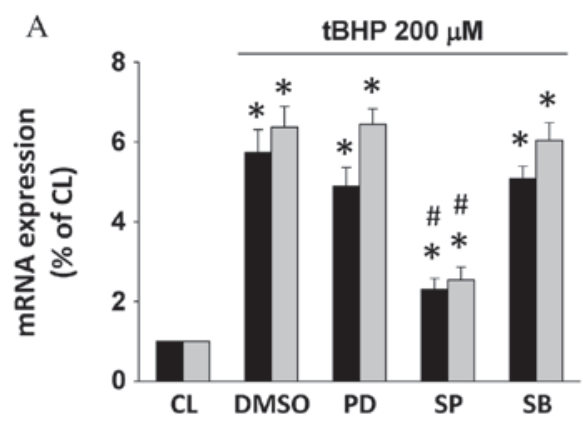

B

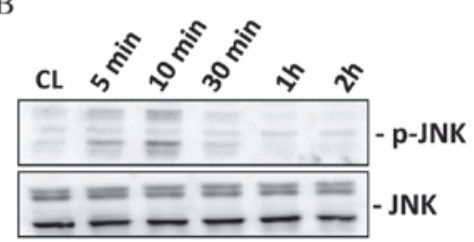

$\mathrm{C}$

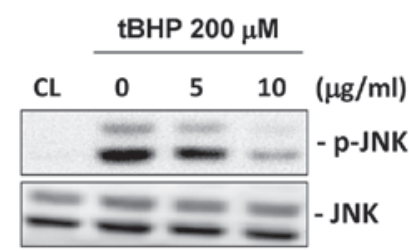

Figure 5. Black garlic extract inhibits IL-6 and IL-8 mRNA expression levels of tBHP induction through JNK signaling in rat clone-9 hepatocytes. (A) Cells were kept as CL or were treated with tBHP at $200 \mu \mathrm{M}$ for $24 \mathrm{~h}$. Prior to stimulation with tBHP, cells were pretreated with DMSO or MAPK inhibitors (ERK/PD98059, JNK/SP600125 or p38/SB203580) for $1 \mathrm{~h}$. mRNA expression levels of IL-6 and IL-8 were determined by reverse transcription-quantitative polymerase chain reaction. (B) Cells were kept as CL or were treated with tBHP at $200 \mu \mathrm{M}$ for 5, 10 and $30 \mathrm{~min}$, and 1 and $2 \mathrm{~h}$, respectively. JNK phosphorylation was determined by western blot analysis. (C) Cells were kept as CL or were treated with tBHP at $200 \mu \mathrm{M}$ for $24 \mathrm{~h}$. Prior to stimulation with tBHP, cells were pretreated with $0-10 \mu \mathrm{g} / \mathrm{ml}$ black garlic extract for $1 \mathrm{~h}$. JNK phosphorylation was determined by western blot analysis. Data in (A) are presented as the mean \pm standard error of the mean from three independent experiments. ${ }^{~} \mathrm{P}<0.05$ vs. CL cells; ${ }^{*} \mathrm{P}<0.05$ vs. cells treated with $\mathrm{DMSO} / \mathrm{tBHP}$. Results in (B) and (C) are representative of three independent experiments with similar results. tBHP, tert-Butyl hydroperoxide; CL, control; IL, interleukin; JNK, c-Jun N-terminal protein kinase; MAPK, mitogen-activated protein kinase; DMSO, dimethyl sulfoxide; ERK, extracellular signal-regulated kinase.

effect on hepatocytes, the mRNA expression levels of inflammatory markers, IL-6 and IL-8, were determined (Fig. 4). Rat clone-9 hepatocytes were kept as the control or were pretreated with black garlic extracts at $0,2.5,5$ and $10 \mu \mathrm{g} / \mathrm{ml}$ for $1 \mathrm{~h}$ and black garlic extract-pretreated cells were treated with tBHP (200 $\mu \mathrm{M})$ for $24 \mathrm{~h}$. As compared with the control, tBHP significantly induced IL-6 and IL-8 mRNA expression levels in the rat clone-9 hepatocytes $(\mathrm{P}<0.05)$. However, black garlic extracts significantly inhibited tBHP-induced IL-6 and IL-8 mRNA expression levels in a dose-dependent manner in rat clone-9 hepatocytes $(\mathrm{P}<0.05)$.

Black garlic extract inhibits IL-6 and IL-8 mRNA expression levels of tBHP induction via JNK signaling in rat clone-9 hepatocytes. Subsequently, whether the MAPK pathway (ERK1/2, JNK, and/or p38 kinases) mediates the inflammatory effects of tBHP and the antagonized effect of black garlic extracts in hepatocytes was investigated. Rat clone-9 hepatocytes were kept as the control or were pretreated with DMSO or MAPK inhibitors (ERK/PD98059, JNK/SP600125 or p38/SB203580) for $1 \mathrm{~h}$. DMSO- and MAPK-inhibitor-pretreated cells were treated with tBHP $(200 \mu \mathrm{M})$ for $24 \mathrm{~h}$. tBHP was identified to significantly induce IL-6 and IL-8 mRNA expression levels in the DMSO-pretreated rat clone-9 hepatocytes when compared with the control $(\mathrm{P}<0.05)$. However, the inhibition activity of JNK, but not of ERK and p38, blocked these tBHP effects (Fig. 5A). Moreover, tBHP $(200 \mu \mathrm{M})$ also induced transient JNK phosphorylation within 5-10 $\mathrm{min}$ in rat clone-9 hepatocytes 
(Fig. 5B). Rat clone-9 hepatocytes were kept as the control or were pretreated with black garlic extracts at 0,5 and $10 \mu \mathrm{g} / \mathrm{ml}$ for $1 \mathrm{~h}$. Subsequently, black garlic extract-pretreated cells were treated with tBHP $(200 \mu \mathrm{M})$ for $10 \mathrm{~min}$. tBHP induced JNK phosphorylation effectively in the rat clone-9 hepatocytes when compared with the control. However, black garlic extracts inhibited the JNK phosphorylation of tBHP induction in a dose-dependent manner in rat clone-9 hepatocytes (Fig. 5C).

\section{Discussion}

The present study revealed that black garlic was able to attenuate liver injury induced by tBHP through the inhibition of JNK activation in the rat clone-9 hepatocytes. Firstly, this work showed that black garlic restored tBHP-induced cell death of rat clone-9 hepatocytes. Secondly, black garlic decreased tBHP-increased lipid peroxidation, oxidative stress and inflammation in rat clone-9 hepatocytes. Finally, the inhibitory effect of black garlic on tBHP-induced liver cell injury was associated with the downregulation of JNK phosphorylation. Thus, these results contribute to a novel notion about the hepatoprotective potential of black garlic in injured liver cells and elucidate a possible molecular mechanism.

Previous animal studies have investigated the effect of black garlic on hepatoprotection $(5,10-12)$. The present study further established that black garlic contributed to the hindering of tBHP-induced liver cell death, lipid peroxidation, oxidative stress and inflammation. Our results were supported by the physicochemical analysis of black garlic in previous studies, showing that antioxidant components of black garlic, including polyphenol and flavonoid, increased significantly during the preparation process when compared with raw garlic (1,23-25). Natural foods and herbs have always been considered as important and interesting sources in developing healthy foods and drugs as they have fewer side effects, superior acceptability and are inexpensive. Data from previous studies and our studies have demonstrated that black garlic possesses multiple biological functions to antagonize distinctive disease development, including liver disease, cancer and hyperlipidemia among others (10-12,26-29). In addition, it has also been reported that the content of cysteine-containing compounds, the main components responsible for the pungent odor in black garlic, decreased significantly when compared to that in raw garlic after the preparation process (1). Consequently, black garlic is becoming one of a number of popular natural products gradually being introduced into health food and clinical disease treatment in Asian countries, including Taiwan, China and Korea (1).

Abnormal inductions of lipid peroxidation and oxidative stress are common destructive mechanisms in injured liver cells and typically accompany the alteration of the intracellular redox balance $(19,29)$. During these processes, free radicals and other highly reactive substances are significantly produced to induce peroxisomal and microsomal oxidation of fatty acids and mitochondrial dysfunction. Therefore, these reactions seem to have crucial roles in leading to the pathogenesis of liver tissue, including steatohepatitis and fatty liver (30-33). In the present study, MDA accumulation and GSH depletion in rat clone-9 hepatocytes demonstrated that $\mathrm{tBHP}$ was metabolized in cells and therefore induced the imbalance of redox and the occurrence of lipid peroxidation. Moreover, the downregulation of the activities of antioxidative enzymes, such as CAT, SOD and GPx, also demonstrated that intracellular oxidative stress increased under tBHP stimulation. These situations may therefore disrupt the array and composition of membrane lipids and subsequently result in hepatic inflammation and cell death. Efficient neutralized activity of black garlic in tBHP-induced rat clone-9 hepatocytes in the current study suggested that the hepatoprotective effects of black garlic may occur through restoring the intracellular redox, by increasing the antioxidant (GSH) level and antioxidative enzyme (CAT/SOD/GPx) activities.

The present study has indicated that black garlic has the potential to block tBHP-induced liver cell injury, including cell death, lipid peroxidation, oxidative stress and inflammation in rat clone- 9 cells. Moreover, JNK signaling may regulate the hindering effects of black garlic. As a result, the findings of the present study propose that black garlic may have an important role in liver protection. Therefore, this study suggests that a novel perspective on the application of black garlic on the physiological and pathophysiological management of the liver is developing, and warrants further exploration.

\section{Acknowledgements}

The present study was supported by Chang Gung Memorial Hospital-Kaohsiung Medical Center, Chang Gung Memorial Hospital (grant nos. CZRPG880253, CMRPF6A0073, CMRPF6C0032 and CMRPG8C1261), Chang Gung University of Science and Technology and by the National Science Council, Taiwan (grant nos. NSC101-2622-B-255-001-CC3, NSC102-2313-B-255-002, MOST 103-2313-B-255-001 and MOST103-2622-B-255-001-CC3).

\section{References}

1. Choi IS, Cha HS and Lee YS: Physicochemical and antioxidant properties of black garlic. Molecules 19: 16811-16823, 2014.

2. Banerjee SK and Maulik SK: Effect of garlic on cardiovascular disorders: A review. Nutr J 1: 4, 2002.

3. Rahman K and Lowe GM: Garlic and cardiovascular disease: A critical review. J Nutr 136 (3 Suppl): 736S-740S, 2006.

4. Ha AW, Ying T and Kim WK: The effects of black garlic (Allium satvium) extracts on lipid metabolism in rats fed a high fat diet. Nutr Res Pract 9: 30-36, 2015.

5. Shin JH, Lee CW, Oh SJ, Yun J, Kang MR, Han SB, Park H, Jung JC, Chung YH and Kang JS: Hepatoprotective effect of aged black garlic extract in rodents. Toxicol Res 30: 49-54, 2014.

6. McRae MP: A review of studies of garlic (Allium sativum) on serum lipids and blood pressure before and after 1994: Does the amount of allicin released from garlic powder tablets play a role? J Chiropr Med 4: 182-190, 2005.

7. Ichikawa M, Ryu K, Yoshida J, Ide N, Yoshida S, Sasaoka T and Sumi S: Antioxidant effects of tetrahydro-beta-carboline derivatives identified in aged garlic extract. BioFactors 16: 57-72, 2002.

8. Corzo-Martínez M, Corzo N and Villamiel M: Biological properties of onions and garlic. Trends Food Sci Technol 18: 609-625, 2007.

9. Jang EK, Seo JH and Lee SP: Physiological activity and antioxidative effects of aged black garlic (Allium sativum L.) extract. Korean J Food Sci Technol 40: 443-448, 2008.

10. Kim JH, Nam SH, Rico CW and Kang MY: A comparative study on the antioxidative and anti-allergic activities of fresh and aged black garlic extracts. Int J Food Sci Technol 47: 1176-1182, 2012.

11. Lee YM, Gweon OC, Seo YJ, Im J, Kang MJ, Kim MJ and Kim JI: Antioxidant effect of garlic and aged black garlic in animal model of type 2 diabetes mellitus. Nutr Res Pract 3: 156-161, 2009. 
12. Kim MH, Kim MJ, Lee JH, Han LJ, Kim JH, Sok DE and Kim MR: Hepatoproective effect of aged black garlic on chronic alcohol-induced liver injury in rats. J Med Food 14: 732-738, 2011.

13. Kumar A: A review on hepatoprotective herbal drugs. Int J Res Pharm and Chem 2: 92-102, 2012.

14. Senthilkumar R, Chandran R and Parimelazhagan $\mathrm{T}$ : Hepatoprotective effect of Rhodiola imbricata rhizome against paracetamol-induced liver toxicity in rats. Saudi J Biol Sci 21: 409-416, 2014

15. Tacke F, Luedde $\mathrm{T}$ and Trautwein $\mathrm{C}$ : Inflammatory pathways in liver homeostasis and liver injury. Clin Rev Allergy Immunol 36 : 4-12, 2009.

16. Sagar R, Bhaiji A, Toppo FA, Rath B and Sahoo HB: A comprehensive review on herbal drugs for hepatoprotection of $21 \mathrm{st}$ Century. Int J Nutr Pharmacol Neurol Dis 4: 191-197, 2014.

17. Lacour S, Gautier JC, Pallardy M and Roberts R: Cytokines as potential biomarkers of liver toxicity. Cancer Biomark 1: 29-39, 2005.

18. Hinson JA, Reid AB, McCullough SS and James LP Acetaminophen-induced hepatotoxicity: Role of metabolic activation, reactive oxygen/nitrogen species, and mitochondrial permeability transition. Drug Metab Rev 36: 805-822, 2004.

19. Kučera O, Endlicher R, Roušar T, Lotková H, Garnol T, Drahota Z and Cervinková Z: The effect of tert-butyl hydroperoxide-induced oxidative stress on lean and steatotic rat hepatocytes in vitro. Oxid Med Cell Longev 2014: 752506, 2014.

20. Bellomo G, Thor $\mathrm{H}$ and Orrenius S: Increase in cytosolic $\mathrm{Ca} 2+$ concentration during t-butyl hydroperoxide metabolism by isolated hepatocytes involves NADPH oxidation and mobilization of intracellular Ca2+ stores. FEBS Lett 168: 38-42, 1984.

21. Crane D, Häussinger D, Graf P and Sies H: Decreased flux through pyruvate dehydrogenase by thiol oxidation during t-butyl hydroperoxide metabolism in perfused rat liver. Hoppe Seylers Z Physiol Chem 364: 977-987, 1983.

22. Livak KJ and Schmittgen TD: Analysis of relative gene expression data using real-time quantitative PCR and the 2(-Delta Delta C(T)) method. Methods 25: 402-408, 2001.

23. Block E: The chemistry of garlic and onions. Sci Am 252. 114-119, 1985.

24. Amagase H, Petsch BL, Matsuura H, Kasuga K and Itakura Y: Intake of garlic and its bioactive components. J Nutr 131 (3 Suppl): 955S-962S, 2001.

25. Shin JH, Choi DJ, Chung MJ, Kang MJ and Sung NJ: Changes of physicochemical components and antioxidant of aged garlic at different temperatures. J Korean Soc Food Sci Nutr 37 $1174-1181,2008$
26. Lee EN, Cho YW, Kim HK, Park JK, Kim HJ, Kim MJ, Lee HW, Kim KH, Bae SS, Kim BS and Yoon S: Chloroform extract of aged black garlic attenuates TNF- $\alpha$-induced ROS generation, VCAM-1 expression, NF- $\kappa \mathrm{B}$ activation and adhesiveness for monocytes in human umbilical vein endothelial cells. Phytother Res 25: 92-100, 2011.

27. Kim HK, Choi YW, Lee EN, Park JK, Kim SG, Park DJ, Kim BS, Lim YT and Yoon S: 5-Hydroxymethylfurfural from black garlic extract prevents $\mathrm{TNF} \alpha$-induced monocytic cell adhesion to HUVECs by suppression of vascular cell adhesion molecule-1 expression, reactive oxygen species generation and NF- $\mathrm{\kappa B}$ activation. Phytother Res 25: 965-974, 2011

28. Kim I, Kim JY, Hwang YJ, Hwang KA, Om AS, Kim JH and Cho KJ: The beneficial effects of aged black garlic extract on obesity and hyperlipidemia in rats fed a high-fat diet. J Med Plants Res 5: 3159-3168, 2011.

29. Gambino R, Musso G and Cassader M: Redox balance in the pathogenesis of nonalcoholic fatty liver disease: Mechanisms and therapeutic opportunities. Antioxid Redox Signal 15: 1325-1365, 2011.

30. Cervinková Z, Lotková H, Kriváková P, Rousar T, Kucera O, Tichý L, Cervinka M and Drahota Z: Evaluation of mitochondrial function in isolated rat hepatocytes and mitochondria during oxidative stress. Altern Lab Anim 35: 353-361, 2007.

31. Jaeschke H, Gores GJ, Cederbaum AI, Hinson JA, Pessayre D and Lemasters JJ: Mechanisms of hepatotoxicity. Toxicol Sci 65: 166-176, 2002.

32. Li Z, Berk M, McIntyre TM, Gores GJ and Feldstein AE: The lysosomal-mitochondrial axis in free fatty acid-induced hepatic lipotoxicity. Hepatology 47: 1495-1503, 2008.

33. Kučera $\mathrm{O}$, Roušar T, Staňková $\mathrm{P}$, Haňáčková $L$, Lotková $H$, Podhola M and Cervinková Z: Susceptibility of rat non-alcoholic fatty liver to the acute toxic effect of acetaminophen. J Gastroenterol Hepatol 27: 323-330, 2012.

(i) (9) This work is licensed under a Creative Commons Attribution-NonCommercial-NoDerivatives 4.0 International (CC BY-NC-ND 4.0) License. 